\title{
Low developmental capacity of in vitro matured and fertilized oocytes from calves compared with that of cows
}

\author{
F. Revel ${ }^{1}$, P. Mermillod ${ }^{2}$, N. Peynot ${ }^{1}$, J. P. Renard ${ }^{1}$ and Y. Heyman ${ }^{1}$ \\ ${ }^{1}$ Unite de Biologie du Developpement, INRA 78352, Jouy en Josas, France; and ${ }^{2}$ Physiologie de la \\ Reproduction, INRA 37380, Nouzilly, France
}

\begin{abstract}
The developmental competence of oocytes from 3-month-old calves was studied through in vitro maturation, fertilization and culture up to the blastocyst stage and by embryo transfer into a foster mother. Oocytes were recovered from antral follicles of calves after or without ovarian stimulation with exogenous FSH and their developmental potential was compared with that of oocytes recovered from cow ovaries. Fertilization and cleavage rates from calf oocytes did not differ significantly from those of cow oocytes. However, after 7 days of culture, the blastocyst formation rate was significantly lower for calves ( $9 \%$ and $11 \%$ for nontreated and treated animals, respectively) than for cows (over 20\%). Transfer of blastocysts obtained from calf oocytes resulted in a lower pregnancy rate ( 1 of 23 recipients; $4 \%$ ) than that achieved with cow oocytes (10 of $26 ; 38 \%$ ). The recipient cow that was pregnant from calf embryos delivered a full-term live calf. These data show that some key regulative event that determines the ability to form blastocysts in cattle has not been fully achieved in oocytes from 3-month-old calves.
\end{abstract}

\section{Introduction}

Oocytes from antral follicles larger than about $2 \mathrm{~mm}$ in diameter from several mammals are fully grown and can resume meiosis spontaneously: cows and pigs (Motlik and Fulka, 1986), sheep (Jagiello et al., 1975; Szöllösi et al., 1988) and goats (De Smedt et al., 1994). Several lines of evidence show that the ability of these oocytes to resume meiosis depends on their hormonal environment and is associated with sequential changes in follicular steroidogenesis. Moor and Trounson (1977) showed that sheep oocytes cultured within the follicle in hormone-free medium reactivated meiosis only after addition of gonadotrophin (FSH and LH). Further experiments, using inhibitors of steroid secretion, showed that maturation of the oocytes requires a specific intrafollicular steroid environment acting synergistically with gonadotrophins (Moor et al., 1980). In vitro, this hormonal influence appears to be beneficial not only for maturation but also for fertilization in mice (Downs et al., 1986), rats (Shalgi et al., 1979), sheep (Galli and Moor, 1991) and cattle (Fukushima and Fukui, 1985; Younis et al., 1989). In cattle, supplementation of the maturation medium with $\mathrm{LH}$ and FSH and oestradiol influences both the fertilization rate and the ability of fertilized eggs to develop normally in vitro up to the blastocyst stage (Saeki et al., 1991).

Fully grown bovine oocytes in antral follicles are present at birth. This is different from species such as mice which are widely used as an experimental model, in which oocytes from 12-day-old prepubertal females have to be grown in vitro before maturation and fertilization to achieve full term

Received I July 1994. development (Eppig and Schroeder, 1989). Comparing calf oocytes with cow oocytes allows examination of how the hormonal environment affects the ability of fully grown oocytes to develop following in vitro maturation and fertilization.

Onset of puberty corresponds to the establishment of a pulsatile pattern of $\mathrm{LH}$ secretion appropriate for the development of an ovulatory surge. In cattle, it is proposed that increases in progesterone play a key role in the establishment of this pattern (Schams et al., 1981). A low concentration of progesterone $\left(<0.1 \mathrm{ng} \mathrm{ml}^{-1}\right)$ is present from 1 to 9 months of age (Schams et al., 1981) and young females become puberal only at about $I$ year of age, depending on breed and body mass. The overall mean LH and FSH concentrations decrease between 3 and 15 weeks after birth, during which time the ovaries remain exposed to a lower hormonal environment than those of cyclic cows (Dodson et al., 1988).

An advantage of the postnatal bovine ovary is that the pool of growing follicles is much greater before puberty, especially between 50 and 120 days of age, than after puberty (Erickson, 1966). This explains why attempts have been made to produce embryos from young calves. Early reports by Onuma et al. (1970) and Seidel et al. (1971) indicated that female calves could respond to exogenous gonadotrophin treatment with follicular growth but that the developmental ability of oocytes was limited to two or three cleavages. However, several groups have reinvestigated the possibility of producing blastocysts from prepubertal female calves using in vitro maturation and fertilization. Cleavage rates higher than 50\% were achieved (Palma, 1994) but data on the ability to develop further remain controversial. Armstrong et al. (1992) obtained a higher rate of blastocyst formation from calf oocytes than from cow oocytes $(27 \%$ 
versus $17 \%$ of cleaved eggs, respectively), but only a small number of oocytes were involved in this experiment. Irvin et al. (1993) found that development rates for calf and cow oocytes were similar (30\% versus $25 \%$, respectively), whereas Palma et al. (1993) who, unlike the two previous authors, did not treat their calves with FSH, obtained a lower blastocyst rate per cleaved egg obtained from calves (16\%).

The objective of the present study was to examine the developmental potential of prepubertal calf oocytes and to determine whether exogenous FSH treatment improves their developmental competence. Their ability to develop into blastocysts after in vitro maturation and fertilization was investigated using material from adult cows as controls. Viability of blastocysts was further assessed in vivo through embryo transfer. Our results show that in vitro development of calf oocytes to the blastocyst stage was significantly lower than that of oocytes from adults and that the further viability of such blastocysts was severely impaired.

\section{Materials and Methods}

\section{Untreated calves}

A total of 78 ovaries were collected from 39 3-4-month-old calves at the local abattoir for five replicate experiments. In each replicate, ovaries from cows were also collected (a total of 116 ovaries). Ovaries were transported to the laboratory in saline at $30-35^{\circ} \mathrm{C}$ and oocytes were aspirated within $2 \mathrm{~h}$ of slaughter from 3-6 mm follicles through an 18 gauge needle under constant vacuum.

Oocytes surrounded by more than three compact layers of cumulus cells were selected, washed and submitted to in vitro maturation and fertilization as described by Mermillod et al. (1992). Briefly, oocytes were matured for $24 \mathrm{~h}$ in pools of about 100 in TCM199 (Gibco, Paisley) containing 10\% (v/v) heat-treated fetal calf serum, I $\mu \mathrm{g}$ oestradiol $\mathrm{ml}^{-1}$ (Sigma, St Louis, MO), $5 \mu \mathrm{g} \mathrm{pLH} \mathrm{ml}{ }^{-1}$ and $0.5 \mu \mathrm{g} \mathrm{pFSH} \mathrm{ml}^{-1}$ (pure pLH and pFSH were provided by J. F. Beckers, Liège). Spermatozoa were prepared on Percoll (Pharmacia, Uppsala) gradients and fertilization was carried out in 4-well tissue culture plates for $18 \mathrm{~h}$ at $39^{\circ} \mathrm{C}$ under $5 \% \quad \mathrm{CO}_{2}$. Each well contained about 100 oocytes and $10^{\circ}$ spermatozoa in $500 \mu \mathrm{l}$ TALP supplemented with $10 \mu \mathrm{g}$ heparin $\mathrm{ml}^{-1}$ (Na salt, $167 \mathrm{U} \mathrm{mg}^{-1}$, Calbiochem, San Diego, CA). After in vitro fertilization, oocytes were cleaned of surrounding cumulus cells by vortex agitation for $1 \mathrm{~min}$ in PBS. Cow and calf oocytes were randomly selected from each replicate and fixed in ethanol after maturation and fertilization, and stained with Hoechst 33342 fluorescent dye to evaluate the fertilization rate. This rate was evaluated as the ratio of number of cleaved eggs + noncleaved eggs with two pronucleitotal number of inseminated oocytes. Remaining presumptive zygotes were cultured $\left(39^{\circ} \mathrm{C}, 5 \% \mathrm{CO}_{2}\right.$ in air) for 7 days in mineral oil overlaid with drops ( $1 \mu \mathrm{l}$ per embryo) of serum free TCM199 previously conditioned on bovine oviduct epithelial cell monolayers (Mermillod et al., 1993). Cleavage was recorded on day 2 of culture ( 3 days after insemination) and blastocyst rate on day 7 ( 8 days after insemination).

\section{Treated calves}

A total of 14 Holstein calves were treated at 3 months of age. Treatment was adapted from Saumande and Chupin (1994), using a combination of a progestagen implant (Norgestomet, Intervet, Angers) inserted s.c. for 4.5 days, and 8 i.m. injections of pFSH given at intervals of $12 \mathrm{~h}$ with a total dose equivalent to $16 \mathrm{mg}$ (NIH-FSH units) (Stimufol, RhôneMerieux). Animals were killed $12 \mathrm{~h}$ after the final pFSH injection at the experimental abattoir of the institute and the ovaries were immediately recovered and transferred to the laboratory.

Control immature oocytes were recovered from ovaries of cows in a local abattoir and subjected to in vitro maturation and fertilization under the same conditions as the calf oocytes. As soon as ovaries arrived in the laboratory, cumulus-oocyte complexes were collected by aspiration from follicles over $3 \mathrm{~mm}$ diameter present at the surface of the ovary of calves or cows. The cumulus-oocyte complexes of calves were allocated to two groups according to the size of follicles they originated from: either small $(3-8 \mathrm{~mm})$ or large $(>8 \mathrm{~mm}$ ) follicles. After washing three times in TCM199 and morphological evaluation, intact cumulus-oocyte complexes, with several dense cumulus cell layers from calf or control cow ovaries were selected for in vitro maturation. This was performed in TCM199 supplemented with $10 \%(\mathrm{v} / \mathrm{v})$ fetal calf serum, $10 \mu \mathrm{g} \mathrm{FSH} \mathrm{ml}^{-1}$ and $1 \mu \mathrm{g} \mathrm{LH} \mathrm{ml}^{-1}$ and $\mathrm{I} \mu \mathrm{g}$ oestradiol ml $\mathrm{ml}^{-1}$ for $24 \mathrm{~h}$ at $39^{\circ} \mathrm{C}$ in a humidified atmosphere of $5 \% \mathrm{CO}_{2}$ and air on a bovine granulosa cell monolayer. At the end of the maturation period, selected cumulus-oocyte complexes were inseminated using the in vitro fertilization as described by Marquant-Le Guienne et al. (1990). Briefly, frozen-thawed sperm cells, separated by the swim up technique and heparin capacitated, were used for

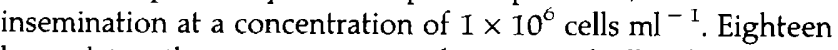
hours later, the eggs were rinsed in Hepes-buffered TCM199 and dechoronized by pipetting before culturing. For each replicate experiment, zygotes from calf and cow oocytes were co-cultured for 7 days at $39^{\circ} \mathrm{C}$ on bovine oviductal epithelial cell monolayers prepared by primoculture 3-5 days before the start of the culture in 4-well dishes (Nunclon-Delta, Roskilde). The cleavage rate was evaluated on day 2 ( 3 days after insemination). Noncleaved embryos were fixed in acetic alcohol, stained with aceto-orcein and observed under the microscope to determine the presence of two pronuclei to evaluate the fertilization rate

On day 7 of co-culture, development was assessed by evaluating the proportion of blastocysts formed from cow and calf oocytes.

\section{Viability assessment of the in vitro derived blastocysts}

Some of the blastocysts that had developed in vitro from oocytes of nontreated or FSH-treated calves and from cow oocytes were transferred to recipient heifers to assess their viability. The calf and cow blastocysts used for transfer were produced during the same series of experiments. One or two blastocysts were non-surgically transferred to each recipient on day 7 of the oestrous cycle. After transfer, each recipient was checked twice daily for return to oestrus. A blood sample was taken by day 21 for a rapid plasma progesterone assay and estimation of initiated pregnancies. Fetal development was 
Table 1. In vitro development of oocytes from untreated calves after in vitro maturation and fertilization, and comparison with cow oocytes

\begin{tabular}{|c|c|c|c|c|c|}
\hline \multirow{2}{*}{$\begin{array}{l}\text { Origin of } \\
\text { cumulus-oocyte } \\
\text { complex }\end{array}$} & \multirow{2}{*}{$\begin{array}{c}\text { Oocytes } \\
\text { recovered } \\
\text { and matured } \\
\text { [Replicates] }\end{array}$} & \multirow{2}{*}{$\begin{array}{c}\text { Oocytes } \\
\text { inseminated } \\
\text { and cultured }\end{array}$} & \multicolumn{3}{|c|}{ Rates of } \\
\hline & & & Fertilization & Cleavage & $\begin{array}{l}\text { Blastocyst } \\
\text { formation }\end{array}$ \\
\hline $\begin{array}{l}\text { Untreated calves } \\
\qquad(n=39) \\
\text { [Range] }\end{array}$ & $\begin{array}{c}750 \\
{[5]}\end{array}$ & 662 & $\begin{array}{c}72 \% \\
(21 / 29)\end{array}$ & $\begin{array}{c}81 \%{ }^{a} \\
(510 / 663) \\
{[76 \%-90 \%]}\end{array}$ & $\begin{array}{c}9 \%{ }^{\mathrm{a}} \\
(55 / 633) \\
{[2 \%-16 \%]}\end{array}$ \\
\hline $\begin{array}{l}\text { Cows (Control) } \\
(n=44) \\
\text { [Range] }\end{array}$ & $\begin{array}{c}560 \\
{[5]}\end{array}$ & 496 & $\begin{array}{c}62 \%^{a} \\
(15 / 24)\end{array}$ & $\begin{array}{c}85 \%{ }^{a} \\
(402 / 472) \\
{[81 \%-89 \%]}\end{array}$ & $\begin{array}{c}21 \%^{\mathrm{b}} \\
(97 / 472) \\
{[12 \%-28 \%]}\end{array}$ \\
\hline
\end{tabular}

Chi-square test: percentages with different letters within the same column differ significantly $(P<0.05)$.

first diagnosed by ultrasonography on some of the recipients on day 35 and pregnancies were then confirmed by rectal palpation after 3 months.

\section{Statistical analyses}

Percentages of fertilization, cleavage and blastocyst formation in each group of calf oocytes were first compared with those of control cow oocytes by means of chi-square analysis.

In addition, to take into account the possible existence of a replication effect and of an interaction between replicates and age, a generalized linear model (with a binomial distribution and a logit link, McCullagh and Nedler, 1989) was used. This application of likelihood ratio tests checks the validity of this model as an additive one. If the model is found to be invalid, this means that there is a significant interaction between replicates and age concerning the rate of blastocyst formation.

Results on the development of embryos in vitro from treated and nontreated calves were presented separately since each experiment was conducted with its own control.

\section{Results}

\section{Rate of blastocyst formation from oocytes of untreated calves}

A mean of 19 cumulus-oocyte complexes per calf was recovered from the 39 calves and a total of 662 cumulus oocyte complexes were matured in vitro and inseminated. They were cultured in parallel to 496 control cumulus-oocyte complexes from ovaries of 44 cows in five replicate experiments. The abilities of calf and cow oocytes to be fertilized, to cleave, and to develop to the blastocyst stage were compared (Table 1).

The fertilization and cleavage rates of the oocytes from calves did not differ from those of cows $(72 \%$ versus $62 \%$ and $81 \%$ versus $85 \%$, respectively). However, after 7 days in culture, the rate of blastocyst formation was lower for the calf than for the cow zygotes ( $9 \%$ versus $21 \%$ ). No interaction between replication and age effects could be found and the rate of blastocyst formation was found to be significantly lower $(P<0.001)$ for calf than for cow oocytes.
Rate of blastocyst formation from oocytes of FSH-treated calves

Treatment of 14 calves with FSH, followed by aspiration of follicles, resulted in an average of $39 \pm 22$ cumulus-oocyte complexes per animal; $79 \%$ of them were morphologically intact. These were used for in vitro maturation and fertilization simultaneously with 278 control cumulus-oocyte complexes from ovaries of 23 cows in nine replicate experiments (Table 2).

Calf oocytes were fertilized and cleaved in vitro in the same proportion as those from cows (fertilization rate $85 \%$ and $87 \%$ and cleavage rate $73 \%$ and $79 \%$, respectively). However, after 7 days of in vitro culture, a smaller proportion of blastocysts developed from calf than from cow oocytes (11\% versus $27 \%$; $P<0.05)$. There was evidence of an interaction between replication and age effects but the additive model remained valid for five of nine replicates and, in those cases, the rate of blastocyst formation was found to be significantly lower $(P<0.001)$ for calf than for cow oocytes.

With FSH treated calves, a mean of 3.3 blastocysts was obtained per treated calf while only 1.4 blastocysts were obtained per nontreated calf. This is a consequence of the greater number of cumulus-oocyte complexes recovered (39 cumulus-oocyte complexes for the FSH-treated versus 19 for the untreated calves) as developmental ability to the blastocyst stage did not differ between oocytes of the two groups ( $9 \%$ for nontreated and $11 \%$ for FSH-treated calves, respectively). The number of blastocysts developed in vitro from individual treated calves was highly variable. About $15 \%$ of the calves produced no blastocyst, while $30 \%$ produced four and another $20 \%$ produced more than six blastocysts. This was a consequence of the variation in number of oocytes recovered from individual animals, which ranged from 10 to 78.

No marked differences were observed in the fertilization and cleavage rates of calf oocytes collected from small or large follicles ( $85 \%$ versus $86 \%$ and $70 \%$ versus $76 \%$, respectively) (Fig. 1). However, after 7 days in vitro, there was $6 \%$ blastocyst formation of oocytes from small follicles compared with $16 \%$ in those originating from large follicles $(P<0.05)$. In both cases, developmental ability remained significantly lower than that of cow oocytes ( $27 \%$; see Table 2 ). 
Table 2. In vitro development of oocytes from FSH-treated calves after in vitro maturation and fertilization, and comparison with cow oocytes

\begin{tabular}{|c|c|c|c|c|c|}
\hline \multirow{2}{*}{$\begin{array}{l}\text { Origin of } \\
\text { cumulus-oocyte } \\
\text { complex }\end{array}$} & \multirow{2}{*}{$\begin{array}{l}\text { Oocytes } \\
\text { recovered } \\
\text { and matured } \\
\text { [Replicates] }\end{array}$} & \multirow{2}{*}{$\begin{array}{c}\text { Oocytes } \\
\text { inseminated } \\
\text { and cultured }\end{array}$} & \multicolumn{3}{|c|}{ Rates of } \\
\hline & & & Fertilization & Cleavage & $\begin{array}{l}\text { Blastocyst } \\
\text { formation }\end{array}$ \\
\hline $\begin{array}{l}\text { FSH treated calves } \\
\quad(n=14) \\
\text { [Range] }\end{array}$ & $\begin{array}{c}554 \\
{[9]}\end{array}$ & 438 & $\begin{array}{c}85 \%^{2} \\
(374 / 438) \\
{[72 \%-95 \%]}\end{array}$ & $\begin{array}{c}73 \%^{\mathrm{a}} \\
(320 / 438) \\
{[60 \%-83 \%]}\end{array}$ & $\begin{array}{c}11 \%^{\mathrm{a}} \\
(46 / 438) \\
{[0 \%-43 \%]}\end{array}$ \\
\hline $\begin{array}{l}\text { Cows } \\
\quad(n=23) \\
{[\text { Range] }}\end{array}$ & $\begin{array}{c}278 \\
{[9]}\end{array}$ & 278 & $\begin{array}{c}87 \%{ }^{a} \\
(243 / 278) \\
{[66 \%-100 \%]}\end{array}$ & $\begin{array}{c}79 \%^{\mathrm{a}} \\
(221 / 278) \\
{[88 \%-96 \%]}\end{array}$ & $\begin{array}{c}27 \% \mathrm{~b} \\
(75 / 278) \\
{[10 \%-44 \%]}\end{array}$ \\
\hline
\end{tabular}

Chi-square test: percentages with different letters within the same column are significantly different $(P<0.05)$.

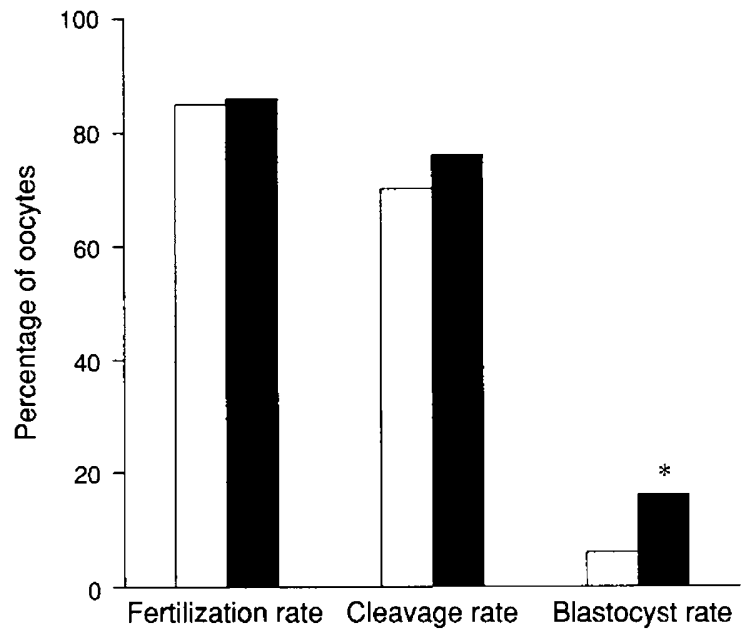

Fig. 1. In vitro development of oocytes from FSH-treated calves according to follicle size. ( $\square$ ) Calf cumulus-oocyte complexes from follicles $3-8 \mathrm{~mm}(n=247)$. ( $)$ Calf cumulus-oocyte complexes from follicles $>8 \mathrm{~mm}(n=191)$. Fertilization rate, cleavage rate and blastocyst rate are related to the number of oocytes inseminated. Statistical notation $\left(^{*}\right)$ is a comparison by means of chi-square analysis of the blastocyst rate of calf oocytes collected from small follicles $(3-8 \mathrm{~mm})$, with that of calf oocytes collected from large follicles $(>8 \mathrm{~mm}), *(P<0.05)$.

\section{Survival in vivo of blastocysts produced in vitro}

Fourteen blastocysts from untreated calves were transferred into 14 recipients (one per recipient); 18 blastocysts from FSH treated calves were transferred into nine recipients (two per recipient); and 26 blastocysts from control cows were transferred into 26 recipients (one per recipient). Rates of initiated pregnancies were $36 \%, 66 \%$ and $65 \%$, respectively. However, only one of nine recipients (11\%) transferred with embryos from treated calves maintained pregnancy and delivered a full-term male calf weighing $45 \mathrm{~kg}$ at birth. This rate is much lower than that obtained after transfer of in vitro matured and fertilized cow blastocysts (38\%). This indicates a higher embryonic or fetal mortality for calf blastocysts than for cow blastocysts developed and transferred under the same conditions (Table 3).

\section{Discussion}

The results reported here show that the developmental ability of embryos obtained in vitro from 3-month-old treated or nontreated calves is significantly lower than that of embryos obtained from cows. This lower developmental ability of calf oocytes has also been reported by Kajihara et al. (1991) and Palma et al. (1993), but differs from results reported by Amstrong et al. (1992) and Irvin et al. (1993). The last two authors observed a higher developmental ability of calf oocytes to the blastocyst stage, but their experiments involved a limited number of oocytes, recovered from young (3-9 weeks of age) FSH-treated calves.

The lower developmental ability of oocytes from 3-monthold calves compared with that of cyclic cow oocytes shown here may depend on some defective endocrine environment encountered in vivo before the onset of puberty. In cattle, the mean LH and FSH concentrations decrease between 3 and 15 weeks of age (Dodson ef al., 1988); therefore the 12-week-old calves used in these experiments probably had lower concentrations of gonadotrophins at the time of oocyte removal.

Hormonal pretreatment of the calves, which combined a progestagen implant and FSH administration, did not improve the developmental ability of the resulting embryos. After stimulation, oocytes from large follices $(>8 \mathrm{~mm})$ developed better than did those from small follicles $(3-8 \mathrm{~mm})$, as has been observed with cow ovaries (Pavlok et al., 1992; Lonerghan et al., 1994), in which there is a relationship between oocyte competence to form a blastocyst and the size of the antral follicle it originates from. Nevertheless, the mean rate of blastocyst formation in calves was always significantly lower than that in cows. Thus, the superovulatory treatment, which is known to stimulate the growth of $2-3 \mathrm{~mm}$ antral follicles (Testart, 1972), resulted in an increased number of available oocytes, but was associated with a higher variability of response between animals. Such variability (ranging from 10 to 78 oocytes recovered per animal) has also been observed after PMSG injection (Onuma et al., 1970; Seidel et al., 1971).

In the study reported here, the lower developmental ability of calf oocytes was observed only from the blastocyst stage onwards. The in vitro fertilization and cleavage rates did not differ from those obtained with oocytes from adult females, but the proportion of morphologically normal blastocysts formed 
Table 3. In vivo survival after transfer of blastocysts produced in vitro from calf and cow oocytes

\begin{tabular}{|c|c|c|c|c|}
\hline \multirow{2}{*}{$\begin{array}{l}\text { Source of } \\
\text { IVF derived } \\
\text { blastocysts }\end{array}$} & \multirow[b]{2}{*}{$\begin{array}{l}\text { Recipients } \\
\text { [Blastocysts] }\end{array}$} & \multicolumn{3}{|c|}{ Pregnancies } \\
\hline & & $\begin{array}{c}\text { Initiated } \\
\text { Day } 21(\%)\end{array}$ & Lost $(\%)$ & $\begin{array}{c}\text { Confirmed } \\
>6 \text { month }(\%)\end{array}$ \\
\hline Untreated calves & $\begin{array}{c}14 \\
{[14]}\end{array}$ & $5 / 14(36 \%)$ & $5 / 5 \quad(100 \%)$ & $0 / 14 \quad(0 \%)$ \\
\hline FSH-treated calves & $\begin{array}{c}9 \\
{[18]}\end{array}$ & $6 / 9 \quad(66 \%)$ & $5 / 6 \quad(83 \%)$ & $1 / 9 \quad(11 \%)$ \\
\hline Control cow oocytes & $\begin{array}{c}26 \\
{[26]}\end{array}$ & $17 / 26(65 \%)$ & $7 / 17 \quad(41 \%)$ & $10 / 26(38 \%)$ \\
\hline
\end{tabular}

was less than half that obtained from cows. The blastocysts derived from calves had a visible inner cell mass and could not be distinguished from those of cows by size or by timing of formation. However, their competence to develop further following transfer to a recipient foster mother was severely limited. Only one recipient of $23(4 \%)$ maintained pregnancy until calving and delivered a full-term live calf, despite a normal rate of initiated pregnancies by day $21(48 \%)$, as assessed by progesterone assay. Pregnancy losses after transfer of blastocysts from calves were more than twice as frequent as losses after transfer of blastocysts from control cows. To our knowledge, there have been only two reports of birth after transfer of embryos from calf oocytes. Armstrong et al. (1992) obtained one calf but, in this case, the transferred blastocysts were derived from oocytes matured in vivo and removed from 5-6-week-old calves. Kajihara et al. (1991) reported the birth of one calf from a blastocyst derived in vitro from oocytes of 4-month-old superovulated calves.

The data presented here have several implications. First, the low developmental ability that characterizes calf oocytes underlines the importance of the follicular microenvironment before puberty. Stimulation of follicular growth by exogenous gonadotrophins for 4 days did not produce in fully grown oocytes the developmental competence that occurs after the onset of puberty. Puberty is not only characterized by the establishment of a pulsatile pattern of $\mathrm{LH}$ secretion, appropriate for the final development of the ovulatory follicle (Schams et al., 1981), but also by a long period of gonadal maturation. Even if the gonads have differentiated enough to respond to an exogenous hormonal stimulation, the number of specific gonadotrophin receptors on target cells may be insufficient (reviewed by Levasseur, 1979). Cell signalling between the oocyte and the surrounding cells within the follicle depends on the presence of these receptors, which make the oocyte more sensitive to its hormonal microenvironment. These maturation events have not occurred in calf oocytes, and this would explain their poor developmental competence.

Second, it appears that some key regulation, which determines the ability to form blastocysts in adult cows, has not been fully achieved in oocytes from 3-month-old calves, even in follicles over $3 \mathrm{~mm}$ in diameter. This 'maternal effect' may also concern the further developmental ability of these blastocysts, and suggests a long-lasting effect of follicular oocyte components on embryonic development. The maternal effect may be related to the presence of an abnormal protein profile observed by Lévesque and Sirard (1994) in untreated calf oocytes, and may arise from qualitative modification in the mRNA population of these oocytes at the beginning of folliculogenesis. The rate of RNA synthesis is high in oocytes of small antral follicles (Motlik et al., 1984; Motlik and Fulka, 1986; Moor and Gandolfi, 1987) and this is necessary for the storage of information (RNAs or proteins) essential not only for resumption of meiosis but also for early embryonic development (Moor and Powell, 1989; Sirard et al., 1992). This finding suggests that some rate-limiting factor(s) of the oocyte is (are) involved in reducing the developmental ability of embryos obtained from female calves. Attempts to identify these factors would require a molecular analysis of groups of oocytes in the same physiological state. If these factors are involved at the mRNA level, then methods are now available for differential screening from a reduced number of cells (Smith and Gridley, 1992; F. Revel, P. Mermillod, N. Peynot, J. P. Renard and Y. Heyman, unpublished).

Finally, these results indicate that caution is required when considering the possibility of using calves for reducing the generation interval in breeding schemes. Whether the low developmental ability observed with oocytes obtained from 3-month-old calves after in vitro maturation and fertilization and embryo transfer will also be encountered in older or even younger animals, remains to be determined. In fact, recent data show that with younger animals (5-week-old calves) a high percentage $(30 \%)$ of blastocysts can be obtained (Armstrong et al., 1994). It is clear that the concept of velogenesis, proposed by Georges (1991), for reducing the generation interval in cattle by using fetal oocytes, needs further experimental confirmation. The feasibility of such an approach has been shown, with limited success, in mice (Eppig and Schroeder, 1989; Carroll et al., 1990), in which oocytes grow for only 15 days (Schultz, 1986). In cattle, oocyte growth lasts at least five times as long (Betteridge et al., 1989) and has not yet been achieved in vitro. This finding, together with the results presented here of experiments using fully grown in vivo oocytes, makes the attractive idea of velogenesis probably a long-term goal.

The authors thank J. L. Touze at INRA Nouzilly, D. Lebourhis for technical assistance, the staff of the experimental farm of INRA for animal care and M. C. Levasseur for critical review of the manuscript. 
C. Chabanet is acknowledged for her help in statistical analysis. This work was partly supported by a grant from Rhône Merieux, the French Ministry of Research and the EU (Biotechnology project Bio2-CT-92-0067).

\section{References}

Armstrong DT, Holm P, Irvin B, Petersen BA, Stubbings RB, McLean D, Stevens G and Seamark RF (1992) Pregnancies and live birth from in vitro fertilization of calf oocytes collected by laparoscopic follicular aspiration Theriogenology 38 667-678

Armstrong DT, Irvin B, Earl C, McLean D, Stevens G and Seamark RF (1994) Gonadotropin stimulation regimens for follicular aspiration and in vitro embryo production from calf oocytes Theriogenology 42 1227-1236

Betteridge KJ, Smith C, Stubbings RB, Xu KP and King WA (1989) Potential genetic improvement of cattle by fertilization of fetal oocytes in vitro Journal of Reproduction and Fertility Supplement 38 87-98

Carroll J, Whittingham DG, Wood MJ, Telfer E and Gosden RG (1990) Extraovarian production of mature viable mouse oocytes from primary follicles Journal of Reproduction and Fertility 90 321-327

De Smedt V, Crozet N and Gall L (1994) Morphological and functional changes accompanying the activation of meiotic competence in ovarian goat oocytes Journal of Experimental Zoology $269128-139$

Dodson SE, McLeod BJ, Haresign W, Peters AR and Lamming GE (1988) Endocrine changes from birth to puberty in the heifer Journal of Reproduction and Fertility 82 527-538

Downs SM, Schroeder AC and Eppig J (1986) Developmental capacity of mouse oocytes following maintenance of meiotic arrest in vitro Gamete Research 15 305-316

Eppig J and Schroeder AC (1989) Capacity of mouse oocytes from preantral follicles to undergo embryogenesis and development to live young after growth, maturation and fertilization in vitro Biology of Reproduction 41 268-276

Erickson BH (1966) Development and senescence of the postnatal bovine ovary journal of Animal Science $25800-805$

Fukushima M and Fukui Y (1985) Effects of gonadotropins and steroids on the subsequent fertilizability of extrafollicular bovine oocytes cultured in vitro Animal Reproduction Science 9 323-332

Galli C and Moor RM (1991) Gonadotrophin requirements for the in vitro maturation of sheep oocytes and their subsequent embryonic development Theriogenology 35 1083-1093

Georges M (1991) Perspectives for marker-assisted selection and velogenetics in animal breeding. In Animal Application of Research in Mammalian Development pp 285-325 Eds RA Pedersen, A McLaren and NL First. Cold Spring Harbor Laboratory Press, New York

Irvin B, Armstrong DT, Earl C, McLean D and Seamark RF (1993) Follicle development and oocyte recovery from calves with repeated gonadotropin stimulation and follicular aspiration Theriogenology 39237 (Abstract)

Jagiello G, Mercedes D, Miller W, Graffeo J and Fang JS (1975) Stimulation and inhibition with $\mathrm{LH}$ and other hormones of female mammalian meiosis in vitro Journal of Reproduction and Fertility 43 9-22

Kajihara Y, Blakewood EG, Myers MW, Kometani N, Goto K and Godke RA (1991) In vitro maturation and fertilization of follicular oocytes obtained from calves Theriogenology 35220 (Abstract)

Levasseur MC (1979) Thoughts on puberty: the gonads Annales de Biologie Animale, Biochimie ef Biophysiaue 19 321-335

Lévesque JT and Sirard MA (1994) Proteins in oocytes from calves and adult cows before maturation: relationship with their development capacity Reproduction Nutrition Developpement 34 133-139

Lonerghan P, Monaghan P, Rizos D, Boland MP and Gordon I (1994) Effect of follicle size on bovine oocyte quality and developmental competence following maturation, fertilization and co-culture in vitro Molecular Reproduction and Development 37 48-53

McCullagh P and Nedler JA (1989) Generalized linear models. In Monographs on Statistics and Applied Probability pp 1-511. Chapman and Hall, London

Marquant-Le Guienne B, Humblot P, Thibier M and Thibault C (1990) Evaluation of bull semen fertility by homologous in vitro fertilization tests Reproduction Nutrition Developpement 30 259-266
Mermillod P, Massip A and Dessy F (1992) In vitro production of cattle embryos: review and Belgian results International Joumal of Developmental Biology 36 185-195

Mermillod P, Vansteenbrugge A, Wils C, Mourmeaux JL, Massip A and Dessy F (1993) Characterization of the embryotrophic activity of exogenous proteinfree oviduct-conditioned medium used in culture of cattle embryos Biology of Reproduction 49 582 -587

Moor RM and Gandolfi F (1987) Molecular and cellular changes associated with maturation and early development of sheep eggs Journal of Reproduction and Fertility Supplement 34 55-69

Moor RM and Powell DJ (1989) Translational capacity of sheep oocytes microinjected with messenger RNA Journal of Reproduction and Fertility $\mathbf{8 6}$ 289-295

Moor RM and Trounson AO (1977) Hormonal and follicular factors affecting maturation of sheep oocytes in vitro and their subsequent developmental capacity Journal of Reproduction and Fertility 49 101-109

Moor RM, Polge C and Willadsen SM (1980) Effect of follicular steroids on the maturation and fertilization of mammalian oocytes Journal of Embryology and Experimental Morphology 56 319-335

Motlik J and Fulka J (1986) Factors affecting meiotic competence in pig oocytes Theriogenology 25 87-96

Motlik J, Kopecny V, Travnik P and Pivko J (1984) RNA synthesis in pig follicular oocytes: autoradiographic and cytochemical study Biology of the Cell $50229-236$

Onuma H, Hahn J and Foote H (1970) Factors affecting superovulation, fertilization and recovery of superovulated ova in prepubertal cattle Journal of Reproduction and Fertility 21 119-126

Palma GA (1994) Effect of FSH and estradiol-17 $\beta$ for maturation of calf oocytes on the in vitro development to blastocysts Theriogenology 41267 (Abstract)

Palma GA, Clement-Sengevald A and Krefft H (1993) In vitro production of cattle embryos from calf oocytes Theriogenology 39278 (Abstract)

Pavlok A, Lucas-Hahn A and Niemann H (1992) Fertilization and developmental competence of bovine oocytes derived from different categories of antral follicles Molecular Reproduction and Development 31 63-67

Saeki K, Hoshi M, Leibried-Rutledge ML and First NL (1991) In vitro fertilization and development of bovine oocytes matured in serum-free medium Biology of Reproduction 44 256-260

Saumande J and Chupin D (1994) Ovarian stimulation in prepubertal heifers Proceedings 10th Scientific Meeting of European Embryo Transfer Association p 244 (Abstract)

Schams D, Schallenberger E, Gombe S and Karg H (1981) Endocrine patterns associated with puberty in male and female cattle Journal of Reproduction and Fertility Suppiement 30 103-110

Schultz R (1986) Molecular aspects of mammalian oocyte growth and maturation. In Experimental Approaches to Mammalian Embryonic Development pp 195-217 Eds J Rossant and RA Pedersen. Cambridge University Press, Cambridge

Seidel GE, Larson LL and Foote RH (1971) Effects of age and gonadotropin treatment on superovulation in the calf Journal of Animal Science 33 617-622

Shalgi R, Dekel N and Kraicer PF (1979) The effect of LH on fertilization and developmental capacity of rat oocytes matured in vitro Journal of Reproduction and Fertility 55 429-435

Sirard MA, Coenen K and Bilodeau S (1992) Effect of fresh or cultured follicular fraction on meiotic resumption in bovine oocytes Theriogenology 37 39-57

Smith D and Gridley T (1992) Differential screening of a PCR-generated mouse embryo cDNA library: glucose transporters are differentially expressed in early postimplantation mouse embryos Development 116 555-561

Szöllösi D, Desmedt V, Crozet N and Brender C (1988) In vitro maturation of sheep ovarian oocytes Reproduction Nutrition Developpement 28 1047-1080

Testart J (1972) Réponse folliculaire du veau femelle impubère a divers traitements de gonadotropine sérique associée ou non a un progestagène Annales de Biologie Animale, Biochimie et Biophysique 12 397-409

Younis AI, Brackett BG and Fayrer-Hosken RA (1989) Influence of serum and hormones on bovine oocytes maturation and fertilization in vitro Gamete Research 23 189-201 